\title{
$\varnothing$ \\ Cabinet governance in New Zealand under MMP: multi-party government and condoned dissent
}

\author{
Dean R Knight*
}

[Published: (2022) 26 Edinburgh Law Review 79-87]

\section{A. INTRODUCTION}

Cabinet government in New Zealand has quietly evolved since the move to proportional representation 25 years ago ushered in an era of multi-party government. Governments formed following elections under the mixed member proportional (MMP) electoral system are routinely comprised of several parties, bound together by coalition, confidence-and-supply, cooperation or other support agreements. As Scotland enters another period of multi-party government, this time under a cooperation agreement, 1 the traditions and practice in the Antipodes may be of interest. Especially instructive is the way the 'unity-distinctiveness' tension has been navigated, evolutionarily, without much drama. ${ }^{2}$

Collective responsibility has been incrementally refashioned. While solidarity in action remains essential, solidarity in voice has become dispensable - at least in some circumstances. The new reality, nowadays carefully reflected in support arrangements between political parties and the hallowed cabinet manual, gives support parties space to voice their distinctiveness and difference. And this move away from steadfast solidarity did not cause the sky to fall. The rhythm of policy- and law-making within Cabinet and Parliament has evolved to reflect the different voices within governance. Support for initiatives cannot be taken for granted, meaning ongoing dialogue and case-by-case compromise is common place.

Faculty of Law and New Zealand Centre for Public Law; Te Herenga Waka-Victoria University of Wellington (dean.knight@,vuw.ac.nz). Thanks, subject to the usual caveat, to Chris Eichbaum, Claudia Geiringer and Michael Webster for comments on draft versions of this note. Thanks also to Maisy Bentley for research assistance.

1 Scottish government and Scottish Green Party parliamentary group, "Cooperation agreement" (1 September 2021).

2 J Boston and D Bullock, "Experiments in Executive Government under MMP in New Zealand" (2009) 7 New Zealand Journal of Public and International Law 39. 


\section{B. EFFECT ON SHAPE OF GOVERNMENT}

New Zealand adopted MMP in 1996 and multi-party government has been the routine for the nine elections held since then. ${ }^{3}$ Parties have joined with others in order to secure the confidence of the House of Representatives necessary to govern (see table below). The nature of the support arrangements has varied, from formal coalitions to confidence-and-supply arrangements to other cooperation arrangements; often a mix of arrangements has been adopted. There is one notable oddity in the multi-party experience: New Zealand's recent 'Covid-19' election, where Jacinda Ardern's Labour party unusually won an outright majority. ${ }^{4}$ But Labour still entered into a cooperation agreement with the Greens, even though it was not necessary to secure the confidence needed to govern. That perhaps testifies to the strength of the tradition of multi-party government.

Table: New Zealand government arrangements under MMP5

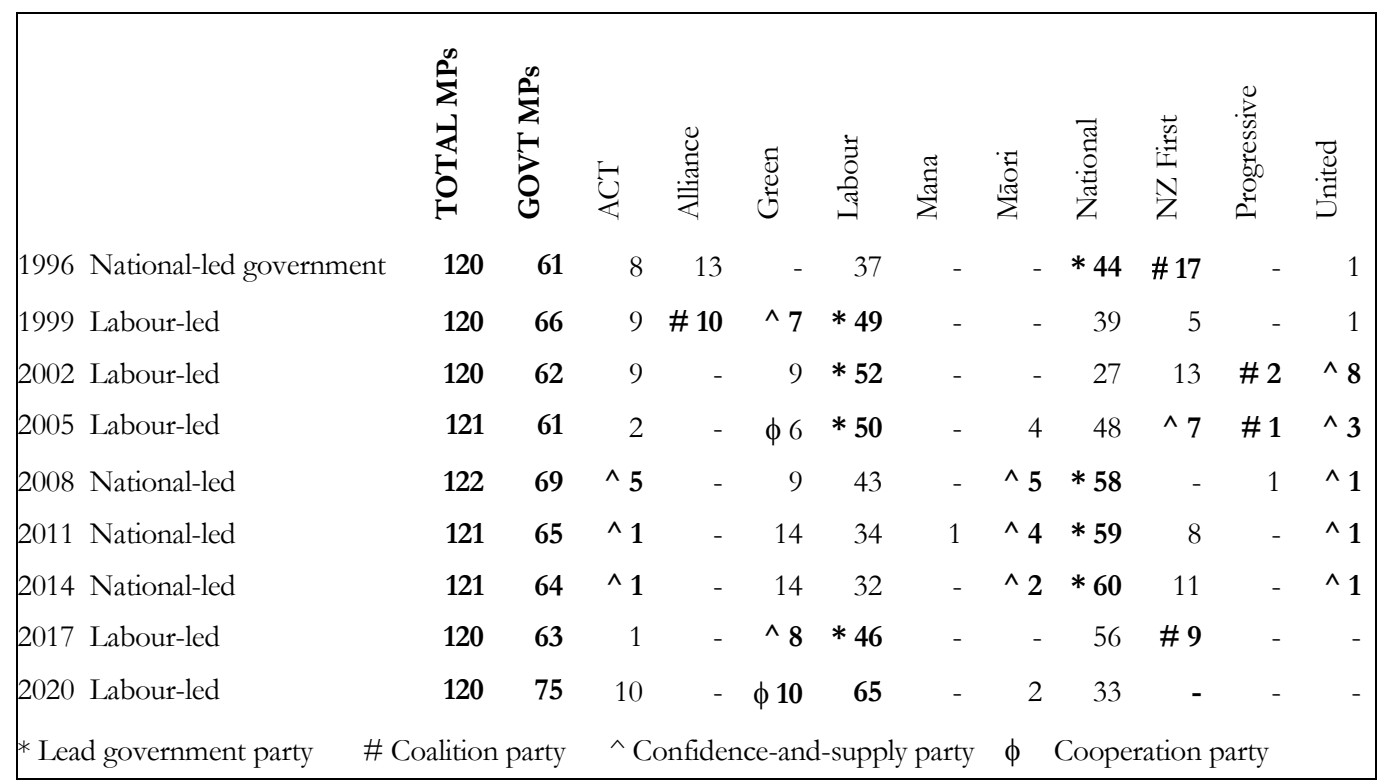

Looking at the pattern of arrangements under MMP over time, history does not remember the first 1996 National-NZ First coalition fondly and it is now seen as an outlier.' As 'kingmaker', NZ First was able to negotiate with both National and Labour; after 8 weeks of suspense, a coalition deal with National

3 See generally MSR Palmer and DR Knight, The Constitution of New Zealand: A Contextual Analysis (Hart Publishing, 2022), chs 4 and 5.

4 DR Knight, "New Zealand: 2020 general election - not an ordinary election, not an ordinary time" [2021] Public Law 439.

5 Table from Palmer and Knight (n 3) at 56; data reflects position on initial government formation only, not subsequent changes.

$6 \quad$ Palmer and Knight (n 3) at 80. 
was agreed. The agreement was extensive and detailed. Ministers from both parties sat in Cabinet. A long list of policy commitments was recorded in the coalition agreement. Strong collective responsibility within the coalition was expected. But the coalition collapsed after less than 2 years following a dispute about the application of collective responsibility to a policy NZ First objected to. Lessons were learned - quickly.

Since then, multi-party arrangements have tended to be looser, focusing more on expectations and processes for relations between parties. Importantly, arrangements more explicitly provide for the management of difference and dissent. Emblematic are confidence-and-supply agreements where, as explained below, only a limited form of collective responsibility applies. Agreements with limited collectivism, such as these, are now the leading way to bind together parties in multi-party government. Coalition agreements only appear occasionally now; other than a recent return in 2017 (between Labour and NZ First), they tended to be used in the early days of MMP where there was strong ideological kinship between the lead government party and smaller support party.

Confidence-and-supply agreements, in general terms, provide for a support party to join the lead party in government. The support party supplies a few ministers - usually designated as ministers outside Cabinet. A high-level policy programme is usually set out, made up of a number of initiatives from each party. Expectations about inter-party engagement are also recorded, including matters such as application of the Cabinet Manual, consultation, no-surprises, confidentially, management of parliamentary business and so forth. In return, the support party agrees to provide support (or, perhaps, abstention) on votes on confidence and supply. For example, the 2017 Labour-Greens agreement recorded: ${ }^{7}$

The Green Party agrees to provide confidence and supply support to a Labour-led Government for the term of this Parliament. The Green Party will oppose any no confidence motions and will support Budgets developed in accordance with this agreement.

Collective responsibility for ministers from confidence-and-supply parties only applies to matters within their portfolios, as explained in more detail below; when speaking about other matters, they do so as leaders of the Greens - not as government ministers.

$7 \quad$ New Zealand Labour Party and Green Party of Aotearoa New Zealand, "Confidence and supply agreement" (24 October 2017) at 1. 
Cooperation agreements have been occasionally adopted too. ${ }^{8}$ These agreements echo the arrangements in confidence-and-supply agreements with two common differences: only agreement not to oppose confidence and supply, and even looser collectivism.

The different names of support agreements (coalition; confidence-andsupply; cooperation) customarily signal the depth of commitment to support the government and mark where an agreement sits on a continuum between strict and loose collectivism. However, in principle, little turns on the name of the agreements: support agreements are bespoke and can weave together different inter-party mechanisms and practices.

One of the struggles of multi-party governance has been governmental nomenclature. In other words, when is a support party properly described as being in government? The term 'government' is not a constitutional term of art. Old fashioned thinking might have reserved the language of government to parties fully subscribed as a coalition, supplying ministers sitting around the Cabinet table. However, the loosening of governance arrangements has prompted more ecumenical language. Governments are now 'Labour-led' or 'National-led'. Support parties with confidence-and-supply agreements are also treated as government parties, even though their ministers are not members of Cabinet and sometimes speak against the government.

Political hijinks about language are not unknown though. For example, in 2017, NZ First was eager to signal its closer relationship with Labour as leadparty relative to the Greens and the administration often used the title 'LabourNew Zealand First coalition, with confidence and supply from the Green Party'. ${ }^{9}$ The current government also often describes itself, oddly, as the 'Labour government', even though they are supported by the Greens under a cooperation agreement and two ministers are drawn from the Greens. ${ }^{10}$ The status of the Greens in 2005 - supporting the Labour-led government under a cooperation agreement - continues to be a puzzle too. ${ }^{11}$ The substance of the agreement echoed arrangements usually seen in confidence-and-supply agreements. But, while the Greens failed to secure ministerial positions, they were designated governmental 'spokespeople' on specific policies they developed in conjunction with the Labour-led government.

8 See eg New Zealand Labour Party and Green Party of Aotearoa New Zealand, "Cooperation agreement" (1 November 2020),

9 Cabinet Office, "Labour-New Zealand First coalition, with confidence and supply from the Green Party: consultation and operating arrangements" (15 December 2017) CO(17)10.

10 Cabinet Office, "Labour government, with support from the Green Party: consultation and operating arrangements" (18 November 2020) CO(20)8.

11 New Zealand Labour and Green Party, "Co-operation agreement" (18 October 2005). 
In any event, the mantle of government tends to cloak an entire political party, not just those with ministerial or other executive roles, if that party contributes members to executive government. That is consistent with the increased prominence of the political party as an institution under MMP. However, it is not without tension, especially when non-ministerial members of support parties speak strongly against the government. All-in-all, this fickleness in language perhaps reminds us that, constitutionally, the underlying practical relationships matter much more than the collective political brand.

\section{EFFECT ON SHAPE OF COLLECTIVE RESPONSIBILITY}

The most striking feature of New Zealand's experience with multi-party government under MMP has been the gradual and significant loosening of solidarity or unanimity expectations under the collective responsibility convention. ${ }^{12}$ Coalition and support parties have been able to publicly express their dissent from governmental decisions in some circumstances. Practically, this provides a safety valve to help manage ideological difference within Cabinet. Optically, it allows a support party to highlight and maintain their distinctiveness. Electorally, it ameliorates the risk that support parties are swallowed up by the lead government party and obliterated at the next election (in practice, a real risk for minor parties under tight coalitions).

The starting point is that the collective responsibility convention continues to apply generally. The Cabinet Manual states: ${ }^{13}$

Once Cabinet makes a decision, Ministers must support it (except as provided [otherwise in the Manual]), regardless of their personal views and whether or not they were at the meeting concerned.

This applies to all ministers, whether inside or outside Cabinet, and whether full ministers, associate ministers or parliamentary under-secretaries. The House of Representatives expresses its confidence in a government as a collective, not individual ministers, and thus solidarity follows. However, a number of exceptions have become commonplace.

First, it is now routine for selective or targeted collective responsibility only to apply to ministers from confidence-and-supply or cooperation parties (ministers from the lead government or coalition parties remain subject to full-blown solidarity expectations). In other words, solidarity is only demanded from such ministers - who, remember, are ministers outside Cabinet - when speaking with their ministerial hat on in relation to matters within their portfolios. This exception 
to solidarity was first employed in the Labour-United confidence-and-supply agreement in 2002 and has since been deeply embedded in multi-party relations. For example, the 2017 Labour-Greens confidence-and-supply agreement records: ${ }^{14}$

The Green Party agrees that any Green Party Minister or Associate Minister is bound by collective responsibility in relation to their respective portfolios. When Ministers speak about issues within their portfolio responsibilities, they will speak for the Government, representing the Government's position in relation to those responsibilities. When Green Party Ministers speak about matters outside their portfolio responsibilities, however, they may speak as Co-Leader and/or members of the Green Party.

This exception is also explicitly reflected in the Cabinet Manual. ${ }^{15}$ Examples of the exercise of this distinctive voice are too numerous to instance because it has become so commonplace. However, it spans the full gamut of policy: from freetrade deals to pandemic public health restrictions to tax and benefit policies. Of course, though, the commitment on confidence-and-supply trumps, so this dissent exception naturally does not extend so far as to allow votes against the government on those fundamental matters.

Secondly, agree-to-disagree provisions allow dissent from Cabinet decisions on an ad hoc party-to-party basis. In other words, Cabinet as a collective can permit the public expression of dissent on a particular matter by a support party. For example, the 2017 Labour-NZ First coalition agreement provided: ${ }^{16}$

$[T]$ he Parties will 'agree to disagree' where negotiated between party leaders, and in such circumstances the Parties will be free to express alternative views publicly, and in Parliament.

Originally, these provisions were designed as the primary mechanism to address dissent during tightly curated coalition arrangements before selective collective responsibility emerged. The agree-to-disagree exception was first seen in the Labour-Alliance coalition agreement in 1999 and was used, for example, to allow the Alliance to vote against a major free-trade deal. Since then, triggering of this dissent mechanism has been relatively infrequent, especially as the need to do so has been overtaken by the liberalisation of solidarity under selective collective responsibility. Regardless, these provisions still appear in coalition agreements and have recently appeared in confidence-and-supply agreements

14 "Confidence and supply agreement" (n 7 ) at 5.

15 Cabinet Office, Cabinet Manual 2017, at [5.29].

16 New Zealand Labour Party and New Zealand First Party, "Coalition agreement" (24 October 2017). 
too. ${ }^{17}$ The Cabinet Manual recognises agree-to-disagree provisions as an exception to collective responsibility (although, oddly, the Manual only speaks of them in relation to coalitions). ${ }^{18}$

Thirdly, in a recent innovation, dissent may be recorded in Cabinet minutes. This exception was first seen in the 2020 Labour-Greens cooperation agreement: ${ }^{19}$

Ministers from the Green Party will not be restricted from noting where that policy may deviate from the Green Party policy on an issue. If this is required, it may be noted in the Cabinet minute that on a key issue, the Green Party position differs from the Cabinet decision

This gives the support party further ability to differentiate themselves from the lead of government. As Cabinet minutes are routinely proactively disclosed, the significance of this exception should not be underestimated. ${ }^{20}$

These three exceptions carve out a large swathe from the solidarity requirement of collective responsibility. There is no doubt that expectations about unity have changed dramatically. Compare, for example, the changing language of the Cabinet Manual. For the first MMP government in 1996, the duty was strong and blunt: 'Ministers whose opposition to a Cabinet decision is such that they wish to publicly dissociate themselves from it must first resign from the Cabinet'. ${ }^{21}$ Over two decades on, the equivalent provision is more diluted: 'Any public dissociation from Cabinet decisions by individual coalition Ministers outside the agreed processes is unacceptable'. ${ }^{22}$

This dilution has led some to proclaim the death of the convention. For example, Joseph now speaks of Cabinet unity as only representing a political ideal, not a constitutional convention. ${ }^{23}$ However, this misunderstands the nature of the convention. Fundamentally, the convention aggregates decisionmaking power to Cabinet, if it wishes to exercise it, and allows for the collective expression of will. If Cabinet makes a decision, it falls on all ministers to ensure it is implemented - regardless of whether they were privy to deliberation about it or whether they personally supported the decision. In other words, ministers must give effect to Cabinet decisions when advising the Governor-General or directing departments within their portfolios. This operational dimension of

17 "Confidence and supply agreement" (n 7) at 5.

18 Cabinet Office, Cabinet Manual 2017, at [5.27]-[5.28].

19 New Zealand Labour Party and Green Party of Aotearoa New Zealand, "Cooperation agreement" (1 November 2020), at [30].

20 Cabinet Office, "Proactive Release of Cabinet Material" (23 October 2018) CO(18)4.

21 Cabinet Office, Cabinet Office Manual 1996, at [3.5].

22 Cabinet Office, Cabinet Manual 2017, at [5.28].

23 PA Joseph, Joseph on Constitutional and Administrative Law, 5th edn (Wellington, Thomson Reuters, 2021) at 294. 
Cabinet collectivism is perhaps so basic that it is easy to overlook. Nothing in the dilution of the expressive dimension of Cabinet collectivism repudiates the need for unity in practice; other constitutional actors called on to act by a minister need to be able to take that minister at their word - that is, their instructions must be taken as reflecting the wishes of collective government. And, in any event, management of dissent continues to be collectively mandated; the parameters of condoned dissent are dictated in government formation negotiations, through the adoption of dissent processes and allocation of ministerial portfolios to support party ministers (thereby delineating the boundaries of dissent). There is no doubt that the collective responsibility convention continues to have constitutional virtue.

\section{EFFECT ON SHAPE OF CABINET AND PARLIAMENTARY PROCESSES}

Multi-party government has also influenced policy- and law-making, both in content and process.

Ideological diversity within government and the legislature means delivery of policy and law is more contestable. The lead government cannot guarantee delivery of their wishes and they generally need to work collaboratively to ensure their initiatives attract the necessary level of support. Thus, MMP largely achieved on the goal of slowing down the law-making process by reducing single-party executive dominance. ${ }^{24}$ One consequence of this is sometimes uneven progress of legislation through Parliament. It not uncommon for support for a bill to be negotiated in stages. Support (and sometimes opposition) parties often agree to first reading and select committee consideration only, with further progression conditional on negotiation of further support. Frequently this causes a lull during negotiation but a rush once support is agreed.

Cabinet's deliberative processes have adjusted to the injection of multi-party government - especially the role of ministers outside Cabinet. However, the 'outside Cabinet' distancing marker should not be overstated because ministers outside Cabinet still heavily participate in Cabinet decision-making. First, Cabinet has two layers - Cabinet itself and Cabinet committees. Much of the work of Cabinet happens in these committees before being perfected by Cabinet itself. Ministers outside Cabinet from support parties are routinely appointed as members of some Cabinet committees. And ministers, whether inside or outside Cabinet, may attend a Cabinet committee when matters within their portfolio responsibility are to be discussed, even if they are not members of the 
committee. ${ }^{25}$ Secondly, ministers outside Cabinet (and parliamentary undersecretaries) may attend Cabinet itself, at the invitation of the Prime Minister. ${ }^{26}$ The frequency of such attendance tends to vary across different administrations. But it is understood to be relatively common for support party ministers outside Cabinet to attend Cabinet for discussion and deliberation on significant matters within their portfolio. ${ }^{27}$ Confidentiality of Cabinet discussions - one of the counterparts to solidarity - continues to be relatively well observed. Only snippets occasionally sneak out and, then, mainly on matters where dissent has been condoned.

MMP needed Parliament to refresh its standing orders - a modernisation project which has continued over the decades that followed. ${ }^{28}$ Most significantly, political parties are more strongly recognised as a key parliamentary institution. For example, votes are almost always cast as party votes (cast as a bloc by the party whip). Committee roles, speaking privileges, and allocation of oral questions to ministers generally reflect the proportionality each party has secured in the House (although, in the case of oral questions, proportion of non-executive MPs only). Thus, multi-party arrangements do not present difficulties for parliamentary proceedings. Some of the politics of parliamentary exchanges may bemuse some though. For example, it is not unknown for a minister from a support party to ask a searching question of a ministerial colleague. But that is a natural consequence of selective collective responsibility.

\section{E. CONCLUSION}

New Zealand has generally taken in its stride the challenges of multi-party government that came with MMP. Governance, institutional and deliberative rules, processes and arrangements have evolved to embrace the expression of different voices within Cabinet government. The loosening of ministerial solidarity - condoning the expression of difference and dissent by support party ministers in some circumstances - is emblematic of this evolution. But this has proved durable. Cabinet's collective processes of deliberation can cope. And allowing support parties to be both in-and-out of government, importantly, maintains their distinctiveness and helps ensure their longer-term electoral prospects.

\section{9}

\footnotetext{
25 Cabinet Office, Cabinet Manual 2017, at [5.62].

26 Cabinet Office, Cabinet Manual 2017, at [5.5].

27 See eg Cabinet Office, "Labour government: operating arrangements" (n 10) at [14].

28 M Harris and D Wilson (eds), McGee: Parliamentary Practice in New Zealand, 4th edn (Auckland, Oratia Books, 2017), ch 2.
} 